\author{
JERZY RAJMAN \\ UNIWERSYTET PEDAGOGICZNY W KRAKOWIE
}

\title{
MUZYKA W DAWNYM ŻYWCU. UNIKATOWA WARTOŚĆ CHRONOGRAFII ANDRZEJA KOMONIECKIEGO
}

\begin{abstract}
$\dot{Z}$ ywiec był miastem niewielkim i peryferyjnie położonym. Bliżej stąd było do śląskiego Bielska i węgierskiej Orawy, niż do Krakowa - stolicy diecezji i województwa. Miasto zawitało na karty historii muzyki w Polsce dzięki zagadkowej postaci organmistrza Jana Wanca, który w I38I r. miał wybudować instrument w pobliskich Kętach. Żywiec lokowany na prawie niemieckim przed 1327 r. posiadał od tego czasu kościół parafialny pod wezwaniem Najświętszej Marii Panny. W XV w. w jego bezpośrednim sąsiedztwie wybudowano zamek². Obie te budowle istnieją do dziś. Materiały źródłowe dotyczące Żywca dostarczają unikatowych wiadomości do dziejów muzyki i to różnych jej odmian - ludowej, kościelnej i dworskiej. Źródło najważniejsze to kronika miasta zatytułowana Chronografia albo Dziejopis Żywiecki napisana w pierwszej ćwierci XVIII w. przez wójta żywieckiego Andrzeja Komonieckiego ${ }^{3}$, który wykorzystał niezachowaną kronikę Andrzeja Kozaka z początku XVII w. ${ }^{4}$, księgi miejskie, a także dokumenty, umowy, testamenty, podania i legendy. Wielką wartość mają informacje dotyczące czasów jemu współczesnych (żył w 1. 1658-1729). Kronika obfituje w opisy dotyczące różnych dziedzin życia, stąd była przedmiotem zainteresowania wielu badaczy'. Na pytanie, czy autor był
\end{abstract}

I Jerzy Golos, The Polish Organ, t. I, The Instrument and its History, Warsaw 1993, s. 303. Kwestii tej postaci i staropolskim organom w Kętach poświęcę osobną publikację.

2 Podstawowe informacje o rozwoju dawnego Żywca podaje Feliks Kiryk, Rozwój urbanizacji Matopolski XIII-XVI w. Województwo krakowskie, powiaty potudniowe, Kraków 1986, s. 309-312, i Zofia Rączka, „Dzieje Żywca do połowy XVII w.”, Karta Groni 5-6 (1974), s. 6-19, 7-8 (1976) s. 34-55.

3 Andrzej Komoniecki, Chronografia albo Dziejopis Żywiecki, wyd. Stanisław Grodziski, Irena Dwornicka, Żywiec 1987.

4 Komoniecki kilkakrotnie się na nią powołuje, zob. s. 90, 183, 289; zob. też: Eugeniusz Janota, Wiadomośc o żywiecczyźnie, Cieszyn 1859, s. VII. Wtórne do Komonieckiego jest dzieło Franciszka Augustina Kroniki Żywieckie od czasów zamierzchtych do I845 $r$. (wyd. Stanisław Grodziski, Zdzisław Jedynak, Rafał Kosiński, Zofia Rączka, Wacław Zyzak, Żywiec-Kraków 2007).

$5 \mathrm{Na}$ szczególną uwagę zasługuje obszerna książka Piotra Kowalskiego Świat Andrzeja Komonieckiego kronikarza Żywca. Studia z antropologii historycznej (Wrocław 20I0). 
w jakiś szczególny sposób zainteresowany muzyką, moglibyśmy odpowiedzieć po analizie wszystkich aspektów życia, jakie Komoniecki opisał. Nie wydaje się jednak, aby muzyka budziła w nim większe zainteresowanie, niż np. drożyzna lub publiczne egzekucje. Niezależnie jednak od tego, jaka byłaby hierarchia zagadnień, które Chronografia porusza, jest dla badań nad historią muzyki źródłem bezcennym. Warstwa informacyjna dotycząca historii muzyki jest niezwykle bogata i w niewielkim stopniu była dotąd wykorzystana ${ }^{6}$.

Niewiele jest u Komonieckiego wzmianek o muzyce, którą moglibyśmy bez obaw zakwalifikować jako ludową ${ }^{7}$, wszystkie jednakże zasługują na przytoczenie i mogą posłużyć jako ważny materiał w dalszych badaniach. W poprzedzającym kronikę opisie najdawniejszych obyczajów autor podał, że uczniowie szkoły parafialnej na sporządzonych przez siebie drewnianych instrumentach imitowali odgłosy ptaków w czasie mszy na Boże Narodzenie ${ }^{8}$. We wzmiance tej dostrzec możemy przejaw przenikania się obyczajów ludowych, widocznych choćby poprzez specyficzne instrumentarium i próbę naśladowania śpiewu ptaków, i stricte kościelnych. Zjawisko to jest doskonale znane w literaturze 9 . Poświadczone są, ogólnikowo, także śpiewy wykonywane podczas jasełek przez uczniów szkół parafialnych ${ }^{\mathrm{ro}}$. Można przypuszczać, że towarzyszyły im ludowe przyśpiewki. O przenikaniu się muzyki stricte kościelnej i ludowej pieśni religijnej świadczą także informacje o litaniach i pieśniach śpiewanych przy kapliczkach w Żywcu (zwyczaj śpiewów majowych, I728 r.). Należy oczywiście dodać, że pieśn religijna wykonywana poza kościołem nie jest muzyką ludową ${ }^{\text {II }}$. Śpiewy, trąbienie i bicie w kotły towarzyszyły wyruszającym z Żywca procesjom, których liczebność szacowano niekiedy na tysiąc osób ${ }^{\mathrm{r}}$. Można przypuszczać, że podczas tak wielkich imprez obok pieśni kościelnych mogły występować przyśpiewki ludowe o tematyce religijnej.

Pojawiła się na kartach kroniki wzmianka o pieśni, którą śpiewał pastuch pasący świnie. Jej treścią było przypadkowe znalezienie przez jedną z podopiecznych pienię-

6 P. Kowalski (op. cit., s. 270 i 287) zwraca uwagę, że Komoniecki pisze o „muzyce” towarzyszącej translacji relikwii św. Jana Kantego, a także, że wpleciony w koło Sebastian w I694 r. śpiewał łacińską pieśń „In manus Tuas Domine commendo spiritum meum redemisti me Deus Veritas commendo spiritum meum”. Pisze także o śpiewanej litanii do N. Marii Panny, gdy skazańca odprowadzano na egzekucję. Współczesne wątki, z uwzględnieniem badań etnograficznych, porusza Józef Mikś („Instrumenty i muzyka Żywiecczyzny", Karta Groni 5-6 (1974), s. 65-74).

7 Bolesław Bartkowski, Polskie śpiewy religijne w żywej tradycji. Style i formy, Kraków 1987 s. 32. O problemach, które towarzyszą analizowaniu pieśni ludowej, zob. także: Jadwiga i Marian Sobiescy, Polska muzyka ludowa i jej problemy, wybór pod red. Ludwika Bielawskiego, Warszawa 1973 (tam obszerna literatura).

8 A. Komoniecki, op. cit., s. 23.

9 B. Bartkowski, op. cit.

Io A. Komoniecki, op. cit., s. 23.

II Ibid., s. 568; Komoniecki pod I660 r. (op. cit., s. 203) podaje informację o procesji idącej z Żywca do Rychwałdu „odprawowaną z kapłanami i ludem pospolitem”. O wykonywaniu pieśni religijnych poza kościołem pisał też Bartkowski (op. cit., s. 53-55).

I2 Np. w I708 r., zob.: A. Komoniecki, op. cit., s. 320. 
dzy w lesie. Komoniecki podaje, że pieśń tę śpiewano w kościele w Radziechowach koło Żywca, ale proboszcz stanowczo tego zakazał'³. W I620 r. wzmiankuje Komoniecki tańce po zakończeniu dziergania $\ln \mathrm{u}^{\mathrm{I} 4}$, nie podaje niestety żadnych szczegółów tej niewątpliwie starej zabawy ludowej.

Jednym z miejsc, gdzie wykonywano muzykę i tańczono, była karczma. W tym przypadku nie mamy wątpliwości, że była to muzyka ludowa. Gospoda w Żywcu wzmiankowana jest po raz pierwszy w wielkim przywileju dla miasta z I448 r. $^{\text {I5 }}$. O muzyce w karczmie czytamy jednak dopiero w aktach sądowych z I6Is roku. Zapisano wówczas mianowicie, że jeden z oskarżonych o przestępstwo zajmował się graniem w karczmie znajdującej się na tzw. Czaczy ${ }^{16}$. Komonieckiemu karczma była, jak się wydaje, doskonale znana, na co wskazują liczne zdarzenia, które opisywał. Przygodnie wśród nich spotykamy informacje o muzyce, jak np. pochodzącą z I705 r. wzmiankę o tańcach w karczmie: wykonujący je mężczyźni mieli na głowach czapki z przyczepionymi kawałkami drewna. Zapewne był to jakiś stary zwyczaj, ale wówczas pojawiło się podejrzenie, że są to tańczące diabły ${ }^{17}$. Kronikarz opisuje także śmierć mieszczanina żywieckiego Dionizego Miodony, która miała go dosięgnąć w roku 1727 podczas tańca. Miodona „odszedłszy trzy razy koło, upadł i umarł”'s. W zapiskach pojawia się także przykład próby przeszczepienia nowego obyczaju, związanego z publicznym muzykowaniem na I maja. Autor podaje pod datą I70I, że miał to być śląski zwyczaj świętowania nowego maja, przeniesiony do Żywca. Towarzyszyła temu muzyka i tańce, ale głównym punktem ludowej zabawy było obnoszenie po ulicach jabłka zatkniętego na szpadę i ozdobionego wstęgami ${ }^{19}$. Wzmianka o szpadzie wskazuje, że ten element z pewnością był nowością, wydaje się jednak, że sama zabawa na początku maja miała bardzo odległa genezę. Opisy zawierają zbyt mało danych, nas zajmuje jednak przede wszystkim ich walor historyczny. Niezwykle interesująca jest wzmianka zapisana pod datą I7I7, że jeden z podsądnych prowadzony na tortury „wesoło śpiewał”20. Czy możemy się tutaj domyślać jakiejś pieśni łotrzykowskiej (zbójeckiej) ${ }^{21}$ ?

Z I7ı6 r. pochodzi pierwsza wzmianka o muzyce góralskiej, która w dziele Komonieckiego występuje pod taką właśnie nazwą ${ }^{22}$. Nie można wykluczyć, że jest to$$
\text { ludową", w: } Z \text { zagadnień polskiej kultury muzycznej. Studia folklorystyczne, red. Adolf Dygacz, Jolanta }
$$
Bauman-Szulakowska, Katowice I994, s. I8, tam też literatura dotycząca muzyki ludowej na Śląsku.

22 A. Komoniecki, op. cit., s. 483. 
w ogóle najstarsza polska wzmianka o muzyce góralskiej ${ }^{23}$. Autor bardzo szczegółowo opisał pewne wydarzenie:

Na zamku urządzono widowisko z okazji pobytu w Żywcu starosty smotryckiego Jerzego Ignacego Lubomirskiego. Co ciekawe, muzykę góralską grano na dziedzińcu zamkowym, autor nie podał niestety, kto był jej wykonawcą. Towarzyszący jej taniec był wykonywany przez pachołków zamkowych. Autor przekazał nawet taki szczegół, że tańcowi towarzyszyły skoki przez ogień. O społecznym pochodzeniu pachołków zamku żywieckiego nie mamy żadnych wiadomości, wątpliwe jest jednak, by można ich określić jako „górali”. Mogli być mieszkańcami przedmieść lub wsi koło Żywca. Kwestia ta jest dość istotna, bowiem zamek magnacki nie był przecież macierzystym miejscem tańca góralskiego. Czytając tę wzmiankę, mamy wrażenie wtórności tego widowiska, wszystko to jednak dowodzi, że muzyka góralska przed I7ı6 r. żywo się rozwijała i jej walory były doceniane, skoro trafiła na zamek Wielopolskich ${ }^{24}$. Widowisko, podczas którego tańczących raczono trunkiem na koszt dziedzica, trwało do północy.

Kościół parafialny był ośrodkiem muzyki (odprawianych w nim mszy śpiewanych i liturgii), której, od pewnego momentu, towarzyszył akompaniament na organach. Zdanie to można odnieść do każdego większego kościoła w dawnej Rzeczypospolitej. W przypadku Żywca źródła pozwalają na w miarę szczegółowe ukazanie roli kościoła parafialnego w rozwoju muzyki, nie tylko stricte kościelnej, ale i edukacji muzycznej, a nawet wizualizacji muzyki. W odniesieniu do schyłku wieków średnich zagadnienie roli muzyki w kościele żywieckim śledzić możemy tylko na podstawie źródeł pośrednich. Należą do nich wzmianki o mszach śpiewanych oraz o osobach, dzięki którym liturgia ta była sprawowana. Wydaje się, że w XV w. pojawiały się w Żywcu mieszczańskie zapisy na konkretne msze w kościele parafialnym. Na uzasadnienie tej hipotezy wskażemy, że z 1542 r. pochodzi wzmianka o "starych przywilejach" na msze przy ołtarzach w kościele żywieckim²5. Pod 1568 r. Komoniecki wspomina o nieszporach i psalmach w tej świątyni ${ }^{26}$. Obowiązki związane z terminowym odprawianiem wszystkich mszy spoczywały na proboszczu i wikarym²7 ${ }^{27}$ ale szczególnie na

23 Maria Małanicz-Przybylska (Między dżwiękami Skalnego Podhala. Wspótczesna góralszczyzna, Warszawa 20I7, s. 92) przytacza najstarsze wzmianki o muzyce góralskiej, ale są to relacje dopiero z I poł. XIX wieku. Wzmianka Komonieckiego jest, rzecz jasna, tylko jednym ze źródeł, które może być przydatne w badaniach nad muzyką góralską. Można tu dodać, że dudy, jeden z podstawowych instrumentów w muzyce góralskiej, były znane już od XVI w., zob.: Adolf Chybiński, Instrumenty muzyczne ludu polskiego na Podhalu, Kraków 1924 (= Prace i Materiały Antropologiczno-Archeologiczne i Etnograficzne 3), s. 83-II3 (tu także o dudach z rejonu Żywca); zob. także: Lidia Długołęcka, Maciej Pinkwart, Muzyka i Tatry, Warszawa-Kraków I992, s. II4.

24 M. Małanicz-Przybylska (op. cit., s. 26-3I) przytacza wiele przykładów zachwytów nad kulturą góralską (najwcześniejsze z I poł. XIX w.).

25 A. Komoniecki, op. cit., s. 68.

26 Ibid., s. 85 .

27 Wikary Jan wzmiankowany jest po raz pierwszy w I 483 r., Archiwum Kurii Metropolitalnej w Krakowie (dalej cyt. AKM), Acta Officialatus Cracoviensis (dalej cyt. AKM, Off.), t. IO, s. I357. 
altarystach, czyli duchownych, których obowiązkiem było śpiewanie mszy przy konkretnym ołtarzu (z tego tytułu mieli odrębne od proboszcza uposażenie). Pierwszy raz o altarii, czyli ołtarzu z uposażeniem dla altarysty, czytamy pod datą $1522^{28}$ jako o altarii już istniejącej (zapewne od XV w.). Późniejsze wzmianki przynoszą kolejne informacje o altariach. W mszach śpiewanych uczestniczył rektor szkoły działającej tu od I poł. XV w. ${ }^{29}$ i kierowany przez niego chór scholarów ${ }^{30}$. Liczne obowiązki liturgiczne, których świadectwem są msze (pierwszy ich szczegółowy wykaz pochodzi z końca XVI w.), wymagały od kleru sumienności. Bywało z tym różnie, ale nawet najbardziej rzetelny lub posiadający kwalifikacje muzyczne ksiądz ${ }^{31}$ potrzebował w śpiewaniu wykwalifikowanego pomocnika, którym był kantor. W większych miastach polskich są znani już w średniowieczu, w przypadku Żywca słyszymy o kantorze dopiero w 1552 r., kiedy poświadczony został Wawrzyniec z Radomska, jako „były kantor w Żywcu” ${ }^{2}$. Odnotowano go jako „niegdyś kantora”, co oznaczać może, że zrezygnował, a powodem rezygnacji były zapewne niskie zarobki. Jeśli nie istniało odrębne uposażenie dla kantora (podobnie jak dla organisty), opłacany był z kasy parafii, to zaś powodowało liczne konflikty.

Przejawem troski o dobry stan muzyki w danym mieście było pojawienie się stałych uposażeń dla organisty, kantora, a czasem i innych muzyków. W Żywcu trud ten wzięła na swe barki możnowładcza rodzina Komorowskich, władająca miastem od II poł. XV wieku. W I550 r. król Zygmunt August zatwierdził zapis dziedziców Jana i Wawrzyńca Komorowskich. Z czynszu na dobrach Gilowice, Ślemień i Kocoń miało być wypłacane 50 złotych rocznie na utrzymanie plebana, dwóch altarystów, rektora szkoły, organisty i dzwonnika ${ }^{33}$. Był także zapis z tego samego roku Krzysztofa Komorowskiego, kasztelana sądeckiego, według którego kantor miał pensję 40 zł rocznie, którą dzielił z dwoma „astantami” („z dwoma młodzieńcami”) ${ }^{34}$. W I6r9 r. pojawił się zapis Mikołaja Komorowskiego dla muzyków i kantorów kościoła w Żywcu. Osoba ta nie cieszy się w historii Żywca dobrą opinią, a i wspomniany zapis był

28 AKM, Acta Episcopalia Cracoviensia, t. 9, k. 8r. O dwóch altarystach żywieckich wspomina pod I556 r. Komoniecki (op. cit., s. 79).

29 Na podstawie opisu Komonieckiego (op. cit., s. 230) można stwierdzić, że budynek szkoły pochodził z I440 roku. Rektora szkoły dotyczy wzmianka z I5I3 r. o „ministrze” kościoła w Żywcu, Archiwum Kapituły Katedralnej w Krakowie, rps sygn. Reg. C. I, s. 78.

30 Był to główny obowiązek uczniów szkoły parafialnej, zob.: Jakub Kubieniec, Secundum consuetudinem. Śpiew godzin kanonicznych w średniowiecznej metropolii gnieźnieńskiej, Kraków 2013, s. 215.

3I A. Komoniecki (op. cit., s. I79) podaje pod I645 r. o Andrzeju Chytrzeńskim rodem z Żywca, plebanie w pobliskiej Jeleśni, że był to „muzyk dobry”. Widzieć w tym możemy ocenę kwalifikacji muzycznych kapłana.

32 AKM, Off., t. 84, s. IO2.

33 F. Lenczowski, op. cit., s. 52; o tym zapisie także A. Komoniecki, op. cit. s. 69, 424. Zob. też: Adam Kamiński, „Komorowski Jan z Komorowa, herbu Korczak, kasztelan oświęcimski”, w: Polski Stownik Biograficzny (dalej cyt. PSB), t. I3, Wrocław 1967-68, s. 4I7, gdzie wzmianka o tym przywileju.

34 A. Komoniecki, op. cit., s. I54. Wspomnienie o dawnym zapisie Krzysztofa Komorowskiego dla muzyków dołączone do opisu z I628 r., zob. także u Komonieckiego na s. 430, 69 i 424. 
specyficzny, bowiem dziedzic przerzucił obowiązek opłacania muzyków na młynarzy, a mianowicie młynarz w Trzebini miał wypłacać kantorowi 40 zł rocznie, a inni muzycy mieli otrzymywać tyleż samo od młynarza w Jeleśni. Młynarz w sąsiednim Przyborowie też miał płacić 40 zł rocznej pensji, ale dla organisty. Mieli mieć to wypłacane na każde tzw. „suche dni”" ${ }^{55}$. Zarządzenie wywołało protesty tych młynarzy, czemu trudno się dziwić.

Szczegółowe wzmianki pochodzące z końca XVI w. przynoszą wiadomości o licznych mszach w obu żywieckich kościołach ${ }^{36}$ oraz o przechowywanych w zakrystii księgach liturgicznych, takich jak mszał rzymski, graduał, antyfonarz i psałterz ${ }^{37}$. Do dziś zachowały się resztki niektórych z nich, a na szczególną uwagę zasługuje pergamin, na którym zapisano nuty i tekst pieśni o św. Andrzeju. Datowany jest na wiek $\mathrm{XVI}^{38}$. Pod koniec XVI w. odnotowano w kościele parafialnym obowiązek odprawiania mszy na cześć Wniebowzięcia N. Marii Panny (we wtorki), mszy za grzechy (w środy), mszy ku czci N. Marii Panny (soboty) i mszy za zmarłych (w piątki). Odrębny porządek mszy miała kaplica z ołtarzem Wniebowzięcia N. Marii Panny. Odbywały się tam cztery msze tygodniowo: w poniedziałki do Trójcy Świętej, we wtorki za zmarłych, w piątki o Męce Pańskiej, a w soboty do Narodzenia N. Marii Panny. W kościółku Krzyża Świętego kapłan miał obowiązek w każdy czwartek śpiewać mszę do Bożego Ciała, a w piątek mszę za zmarłych. Były także nabożeństwa odprawiane dla bractw religijnych. Komoniecki przywołuje notatkę z I59I r., informującą, że Jan Harski, burmistrz żywiecki, zapisał w testamencie pewną sumę na mszę śpiewaną przy ołtarzu bractwa Różańca w Żywcu. Dodaje jeszcze, że „na każde święto chorałem mieszczanie śpiewają”39. Wymienione wyżej nabożeństwa miały zapewne charakter mszy śpiewanych. Zostały odnotowane, jak wspomniano, w I598 r., ale jest oczywiste, że stan ten był wynikiem wieloletniego rozwoju. Do starych mszy dodawano nowe. Tytułem przykładu wskażemy, że w I7I8 r. pojawia się msza śpiewana ku czci św. Joanny tercjarki franciszkańskiej ${ }^{40}$. W i644 r. poświadczono, że rektor szkoły parafialnej w Żywcu ma obowiązek co piątek śpiewać litanię „De nomine Iesu" ${ }^{11}$. Mieszczanin i rajca Malcher Ostrowski ufundował w I7I8 r. zapis na msze śpiewane przez uczniów w chórze kościoła. Wypłacano z niego po I zł dla uczniów za śpiewanie ${ }^{42}$.

Ibid., s. I33, zatwierdzone przez królową Konstancję w I626 roku. W I628 r. dla muzyków i kantorów w kościele żywieckim jest zapis na młynarza 36 złotych od Mikołaja Komorowskiego (ibid., s. I55).

36 AKM, Acta Visitationis Capituli (dalej cyt. AVCap.), 17, k. 27r-32v.

37 J. Kubieniec, op. cit., s. 406.

38 R. Kosiński, op. cit., s. 23 (nr 9-II). W katalogu tym znajdujemy również informacje o zachowanych kartach z XVIII w. z zapisem nutowym (ibid., s. I26 (nr 567)).

39 A. Komoniecki, op. cit., s. I23-I24.

40 Ibid., s. 505 .

4I Ibid., s. 432, o obowiązku tym wspomina także pod I7I3 r. (s. 433).

42 Ibid., s. 505 . 
Wydaje się, że w XVII w. przestano kantorom wypłacać pensję, gdyż pod datą 1699 Komoniecki poświadcza ufundowanie kantorii w kościele żywieckim przez Gabriela Nemeciusa, psałterzysty katedry krakowskiej. Od sumy tysiąca złotych kantor żywiecki miał mieć wypłacane 50 zł rocznie. Franciszek Wielopolski starosta krakowski i pan na Żywcu (Wielopolscy władali Żywcem od I678 r.) zabezpieczył ten zapis na swoich dobrach, Pierwszym kantorem, który korzystał z tego uposażenia, był Bartłomiej Polnarowski, mieszczanin żywiecki ${ }^{43}$.

W I676 r. pojawił się w źródłach nieznany bliżej „Niemiec”, nauczyciel w szkole, a zarazem kantor i muzyk grający na puzonie. Określenie „bakałarz żywiecki” wskazuje, że ukończył sztuki wyzwolone i kierował szkołą parafialną w Żywcu. Autor kroniki zwraca uwagę na interesujące metody pedagogiczne tego bakałarza - chłopców nie bił, lecz częstował smakołykami ${ }^{44}$. Kierował on chórem chłopców uczęszczających do szkoły parafialnej. W I640 r. Krzysztof Mrzygłodowic, rektor szkoły i pisarz miejski, ufundował pulpit wykonany przez snycerza dla chóru małego ${ }^{45}$. W 1732 r. zapisano, że chór dla śpiewaków znajdował się w pobliżu ołtarza Matki Boskiej Pocieszenia, na południe od ołtarza głównego ${ }^{46}$.

Zachowały się liczne wzmianki o konkretnych utworach śpiewanych podczas świąt lub przy innych okazjach. Komoniecki wspomina o pieśni Salve Regina jako bardzo dawnej ${ }^{47}$. Śpiewane godzinki do N. Marii Panny oraz śpiewana msza bractwa maryjnego poświadczone są w I694 r.48. Z kolei w I713 r. poświadczone są „morawskie pieśni o N. Marii Pannie", które jakaś uboga kobieta z Moraw śpiewała na cmentarzu w Żywcu ${ }^{49}$. Z I7I5 r. pochodzi ważna informacja, że w święto Niepokalanego Poczęcia N. Marii Panny dzieci śpiewają kantylenę przed ołtarzem: „Jako róża między kolącym głogiem, Tak Maria między ludzkim narodem, Powstała bez zmazy śliczna panienka jako jutrzenka”. Zwyczaj ten wprowadził Marcin Skórkowski, organista żywiecki ${ }^{5 \circ}$. Repertuar pieśni maryjnych był więc bogaty.

W I6I2 r. pieśni o Męce Pańskiej śpiewała pierwsza procesja z Żywca idąca do Kalwarii Zebrzydowskiejx. Pod I668 r. notujemy antyfonę „Najdroższą krwią swoją odkupiłeś nas Panie” w wersji polskiej. Na uwagę zasługuje fakt, że Krzysztof Mrzygłodowic, pisarz miejski, odszukał w jakimś zbiorze także wersję łacińską wieku, Lublin 1983 , s. 215.

45 A. Komoniecki, op. cit., s. 43I.

46 AKM, rps AVCap. 6I, s. I087.

47 A. Komoniecki, op. cit., s. 24.

48 Ibid., s. 256, a także s. 316.

49 Ibid., s. 438.

50 Ibid., s. 478-479.

5 I Ibid., s. I26.

52 Ibid., s. 2 I2. 
poświadczona jest pasja śpiewana przez proboszcza Mikołaja Fołtyńskiego ${ }^{53}$. Uroczyste Te Deum laudamus zabrzmiało w kościele w i669 r., kiedy król Jan Kazimierz zjawił się, już po swojej abdykacji w Żywcus4. Pieśń pogrzebowa Lacrimosa dies illa śpiewana podczas przechodzenia konduktu wzmiankowana jest w I67I r. ${ }^{55}$. Łamany kołem Sebastian Doboszowic w trakcie kaźni odśpiewał po łacinie In manus Tuus Domine commendo spiritum meum (1694) ${ }^{56}$.

Interesującą relację Komoniecki zamieszcza o kantylenach i psalmach, które umiał na pamięć Sebastian Mrzygłodowic, rektor szkoły parafialnej i kantor w kościele, rodem z Żywca. Przypisuje mu ponadto komponowanie „dialogów”, nie wiadomo jednak, dlaczego nazywa Mrzygłodowica „człowiekiem ciemnym, ale wielce dowcipnym" 57 . Warto dodać, że to już drugi żywczanin o nazwisku Mrzygłodowic udanie zapisujący się w historii kultury muzycznej miasta. Jakieś „pieśni polskie” śpiewał w I7Io r. zakonnik z Nowej Kalwarii pod Warszawą (z tamtejszego zakonu oratorianów), który zawędrował do Żywca. Biczował się przy tym publicznie ${ }^{58}$.

Pozytyw w kościele parafialnym w Żywcu pojawił się przed połową XVI wieku. Instrument ten był ukazany na nieistniejącym już dzisiaj malowidle w kościele, pochodzącym z I542 roku. Mamy ponadto ważny przekaz źródłowy, a mianowicie cytowany już wcześniej przywilej Komorowskich z I550 r., którzy stworzyli stałe źródło dochodów dla organisty i rektora szkoły oraz dla kantora ${ }^{59}$. Był także zapis Krzysztofa Komorowskiego, kasztelana sądeckiego, według którego organista miał pobierać 30 zł rocznie ${ }^{60}$. Podkreślić należy, że rektor szkoły i organista zostali w przywileju z I550 r. wymienieni odrębnie, co oznacza, że zawody te były w Żywcu wykonywane przez różne osoby. Jest to konstatacja ważna, gdyż wskazuje, że organista żywiecki nie był obarczany pozamuzycznymi obowiązkami. Wielokrotnie spotykamy się bowiem z sytuacją, że organista był równocześnie rektorem szkoły. Przyczyna takiego rozwiązania była dość prozaiczna - wykorzystując fakt, że organista miał jako takie kompetencje do uczenia śpiewu, parafia płaciła tylko jedną pensję. Na utrzymanie organisty łożyło także miasto: w I598 r. odnotowano, że rada miejska wypłacała „magistrowi organorum” tygodniowo 40 groszy $^{61}$. Należy podkreślić, że było to wysokie

Ibid., s. 220

Ibid., s. $2 \mathrm{I} 3$.

Ibid., s. 219 .

Ibid., s. 254 .

Ibid., s. 237

Ibid., s. 342.

F. Lenczowski, op. cit., nr 52; o tym zapisie także Komoniecki (op. cit., s. 69, 424). Zob.: A. Kamiński, op. cit., s. 4I7, gdzie wzmianka o tym przywileju. Komoniecki (op. cit., s. 79) wspomina o organach w kościele żywieckim pod rokiem I555, ale relacja ta nie jest zbyt jasna (informacja z I555 r. jest wpleciona w opis odmalowywania całego kościoła „okrom chóru zatylnego, gdzie teraz organy są wielkie”).

60 A. Komoniecki, op. cit., s. I54, 430 (wspomnienie o dawnym zapisie Krzysztofa Komorowskiego dla muzyków dołączone do opisu z I628 r.).

6I AKM, AVCap. I7, k. 30v. 
uposażenie, wskazujące na dbałość o materialne podstawy życia najważniejszego muzyka w mieście. Nazwisko muzyka, który grał na pozytywie w czasie, gdy Komorowscy w 1550 r. dokonywali wspomnianego uposażenia, nie dochowało się w źródłach. Pierwszym znanym nam z imienia organistą w Żywcu był Sebastian Veniqua, odnotowany w źródle w 158I roku. Dziedzic Krzysztof Komorowski' ${ }^{62}$ darował mu plac pod budowę domu w mieście, a w 1585 r. dał mu zagrodę położoną za młynem nad Koszarawą ${ }^{63}$. Veniqua, niewątpliwie z pochodzenia Włoch, zadomowił się w Żywcu i spolonizował, skoro w 1626 r. poświadczony jest jego syn, mieszczanin żywiecki Szymon Chyła ${ }^{64}$. Veniqua grał na instrumencie, o którym nie mamy niestety żadnych wiadomości. Przypuszczać można, że był to pozytyw ufundowany przez właściciela Żywca. Z 1585 r. pochodzi cenna wiadomość, że organy początkowo stały „na chórze nad ołtarzem Wieczerzy Pańskiej”. Komoniecki dodaje, że „obecnie” - czyli w jego czasach (przełom XVII i XVIII w.) - jest tam obraz przedstawiający Mękę Pańską. Ich budowniczym był w 1585 r. organmistrz Stanisław Bartodziejski, o którego pochodzeniu niestety nic nie wiemy. Koszty budowy poniósł właściciel miasta, Jan Spytek Komorowski, podczaszy dworu królowej Katarzyny, ale nie podano ich wysokości ${ }^{65}$. Organy te zostały odnotowane, bez żadnych szczegółów, w protokole powizytacyjnym z $1598 \mathrm{r}^{66}$. Komoniecki napisał jeszcze, że organy Bartodziejskiego miały „starodawną strukturę” i zostały unowocześnione w I686 r. oraz przeniesione na "chór tylni” (pod tą nazwą kryje się chór muzyczny nad zachodnim wejściem do kościoła $)^{67}$. Z kontekstu informacji autora wynika, że znał ten instrument $\mathrm{z}$ autopsji oraz że początkowo (XVI w.) znajdował się on nie na chórze zachodnim, lecz w innym miejscu - prawdopodobnie w prezbiterium ${ }^{68}$. Czytamy pod datą I64I, że runęło sklepienie na chór muzyczny (,zatylny”) w kościele w Żywcu, „gdzie organy postawione są" ${ }^{69}$. W I642 r. wybudowano nowe sklepienie, gdzie, jak pisze Komoniecki, „wielkie organy przestawione są"7o. Wzmianki te sugerują, że w I poł. XVII w. organy znajdowały się na „chórze zatylnym”, czyli nad zachodnim wejściem do kościoła.

62 Krzysztof Komorowski, kasztelan sądecki, był bratem Jana i Wawrzyńca. Filiację podaje Feliks Kiryk w haśle osobowym „Komorowski Mikołaj herbu Korczak, starosta spiski”, PSB, t. I3, Wrocław I96768, s. 425. Krzysztof Komorowski nie ma swojego biogramu w PSB.

63 A. Komoniecki, op. cit., s. 94, 98.

64 Ibid., s. I45.

65 Ibid., s. 98 i 240.

66 AKM, AVCap. 17, k. 27r.

67 Chór ten był sporych rozmiarów, skoro zmieściła się na nim kapela dworska, por.: A. Komoniecki, op. cit., s. 460 .

68 Ibid., s. 98.

69 Ibid., s. 176. Zaraz potem pisze, że ufundowano je z datków wiernych (szczególnie dużo dał zapis Grzegorza Mędrali, mieszczanina żywieckiego), co sugeruje, że mieszczanie złożyli się na budowę. Narracja w tym miejscu nie jest jasna, ale z kontekstu wynika, że datki mieszczan były przeznaczone na odbudowę sklepienia, a nie organów.

70 A. Komoniecki, op. cit., s. I76. Wydaje się, że wzmianka o „przestawionych organach” sugeruje odniesienie się do wydarzeń późniejszych, a mianowicie do przeniesienia organów w I686 r. na chór zatylny. 
W innym miejscu Komoniecki pisał jednak, że dopiero w I686 r. przeniesiono na chór zachodni stare organy Bartodziejskiego. W protokole powizytacyjnym z I644 r. poświadczono organy „elegancko wykonane”71, ale nie podano ich lokalizacji. Jednakże wizytatorzy z I655 r. odnotowują organy (dodam, że na chórze zachodnim) oraz pozytyw w prezbiterium przed głównym ołtarzem ${ }^{72}$. Wskazywałoby to na prawdziwość wersji o organach na chórze zachodnim w I poł. XVII wieku. Przede wszystkim podkreślić trzeba, że protokół z I655 r. poświadcza istnienie dwóch instrumentów - organów głównych i pozytywu.

Z I64I r. pochodzi zapis mieszczki Magdaleny Stolarzyckiej, wdowy po rajcy Piotrze Stolarzyku, która przeznaczyła ogródek na uposażenie każdorazowego organisty w kościele żywieckim. Pierwszym, który z tego uposażenia korzystał, był organista Walenty Perowic ${ }^{73}$. W I686 r. organmistrz Marcin Fabrycjusz na koszt proboszcza Wojciecha Symelliusa przebudował instrument zgodnie z „nową strukturą i modą”. Dekorację malarską wykonał niejaki Rybotycki z Krakowa ${ }^{74}$. Nie mamy informacji także o organmistrzu Marcinie Fabrycjuszu. Instrument przez niego zbudowany funkcjonował przez ćwierć wieku. Muzyki na nich granej słuchał Komoniecki. Opisywał, że „organy w melodiej u rezonacyjej dosyć wdzięczne i w śpiewaniu pięknie zgadzające się z strukturą wielce i malowaniem ozdobne [...] głosem swym chwałę Pana Boga dawały i kościół uweselały [...]”75. Bez szczegółów autor wzmiankuje te organy pod 1706 r. $^{76}$. W I7II r. nadawały się do remontu. Komoniecki opisał pod tym rokiem, że miech wielki w kościele żywieckim, „pod wieżą w kalkowni” wskutek długiego używania, „żałobliwie, głośno, jakoby płacząc i krzycząc, głosy różne z siebie skrzypiąc przeraźliwie wydawał”. Zakłócało to nabożeństwo, ale ciekawe jest spostrzeżenie, że ludzie ówcześni w Żywcu uznali te dźwięki za wyraz żalu, że organy są w ruinie ${ }^{77}$. Podkreślimy również, że zdaniem naszego dziejopisa, skrzypienie i żałosne dźwięki organów były jednym ze zwiastunów pożaru miasta. Wybuchł on 2 VIII I7II r. (w dzień N. Marii Panny Anielskiej). Pożar wywołany został przez piorun, który uderzył w gałkę wieńczącą wieżę kościoła. Opis pożogi można bez przesady określić jako wstrząsający. Zwraca uwagę świadomość autora, że we wnętrzu świątyni wytworzyła się ogromna temperatura. Topiły się nawet kraty kute z grubego żelaza. Oczywiste jest, że organy spłonęły wraz $\mathrm{z}$ całym kościołem ${ }^{78}$. Na podkreślenie zasługuje fakt,

7I AKM, AVCap. 45, s. 94.

72 AKM, AVCap. 46, k. 217r: „organum in opere non exiguo axtruetim est et aliud instrumentum musicum pozytyw in choro minori ante maius altare".

73 A. Komoniecki, op. cit., s. 176.

74 Ibid., s. 98 (to samo na s. 239-240).

75 Ibid., s. 358 .

76 Ibid., s. 304

77 Ibid., s. 356 .

78 Ibid., s. 353-354, autor opisuje bardzo szczegółowo straty, jakich doznał kościół. Utrata organów była jedną z nich. 
że podnosząc z ruiny gmach kościoła postanowiono także szybko je odbudować. I VIII I7I2 r., a zatem w rok po pożarze, w Żywcu pojawił się Jan Głowiński, który przyjechał z Krakowa na prośbę dziedzica miasta ${ }^{79}$. Komoniecki nie charakteryzuje bliżej postaci poważanego dzisiaj organmistrza, wymienia go tak samo, jak wymieniał nazwiska innych organmistrzów pracujących dla kościoła w Żywcu. Z Głowińskim została zawarta umowa, zakładająca, że w ciągu dwóch lat wykona on organy posiadające trzydzieści głosów. W umowie spisano, że budowniczy otrzyma osiemnaście kamieni na piszczałki oraz dowolną ilość drewna na piszczałki drewniane. Jego honorarium miało wynosić 5 tys. złotych ${ }^{80}$. Komoniecki stwierdza, że nie doszło do realizacji umowy z Głowińskim, ale powodów niestety nie podaje. Przyczyną mogła być śmierć krakowskiego organmistrza ${ }^{81}$. W lutym I7ı4 r. były już gotowe organy wykonane przez innego budowniczego, co pozwala przypuszczać, że - licząc tak, jak w przypadku Głowińskiego, dwa lata jako czas budowy - umowę zawarto najpóźniej pod koniec I7I2 roku.

Ważną inwestycją związaną z nowym kontraktem było wybudowanie w I7I3 r. sklepienia pod chór, na którym stanęły później nowe organy. Konstrukcję ukończono Is października. Murarskie prace wykonali Aleksander Kucharski z Gliwic i Jakub Płaza z Jeleśni koło Żywca ${ }^{82}$. W lutym I7I4 r. części do nowego instrumentu kościoła parafialnego w Żywcu przywiózł Ignacy Rysiak z Opawy, którego Komoniecki nazywa „Niemcem i Ślązakiem”", aczkolwiek nazwisko nie wskazuje na niemieckie pochodzenie. Dodał jeszcze, że organmistrz był „chromy”. II lutego przywieziono z Opawy na dziesięciu furmankach części do „korpusu sztuki stolarskiej i snycerskiej”. W tydzień później dostarczono z Opawy „instrumenty organie” (sic!), czyli trąby i piszczałki. Powstały organy o trzydziestu jeden głosach. Rysiak zamontował I545 piszczałek i trąb metalowych, nie licząc drewnianych, których liczby nie poda$n^{84}$. Koszt prac stolarskich i snycerskich na chórze wyniósł 1666 zł polskich i 20 groszy, zaś koszt organów to aż 6600 zł polskich. Całość wypłacił dziedzic miasta, część honorarium organmistrz uzyskał w postaci cyny i ołowiu ze starych piszczałek. Czytamy, że piszczałki ze starych organów stopiono, a topnię urządzono na cmentarzu

79 O planowanej pracy Głowińskiego w Żywcu nie wspomina się w biogramach jemu poświęconych, zob.: Józef W. Reiss, „Głowiński Jan”, PSB, t. 8, Wrocław I959-I960, s. I3I; Aleksander Pawlak, „Głowiński Jan”, w: Encyklopedia Muzyczna PWM, część biograficzna, red. Elżbieta Dziębowska, t. 3, Kraków I987, s. 346. Z prac tych wynika, że nie jest ustalona data śmierci wybitnego organmistrza. Reiss podał, że Głowiński żył jeszcze w I7II r., natomiast Pawlak, że zmarł około I7I2 roku. W tej kwestii konieczna jest dodatkowa kwerenda, przekaz Komonieckiego pozwala stwierdzić, że Jan Głowiński jeszcze w sierpniu I7I2 r. był w Żywcu.

80 A. Komoniecki, op. cit., s. 376.

8I http://www.organypiszczalkowe.pl/zywiec.html, dostęp I5 I 2020.

82 A. Komoniecki, op. cit., s. 438-439.

83 Ibid., s. 444 .

84 Ibid., s. 444, powtarza o tym także na s. 4I7 z jedną drobną różnicą, a mianowicie, że miały być trzydzieści trzy głosy. 
koło szkoły parafialnej. Uzyskano w ten sposób dwa kręgi cyny i pięć ołowiu, co ważyło trzynaście cetnarów i pół kamienia. Każdy cetnar wyceniono na 40 zł polskich - te pieniądze przyjął organmistrz jako rozliczenie całości kosztów ${ }^{85}$. Wynika stąd, że starych piszczałek nie wykorzystano, wszystko było nowe, przyjechało z Opawy. Na inaugurację nowego instrumentu grano w sobotę do śpiewanych „godzinek”, a 24 czerwca odbyła się suma z akompaniamentem organów, „z wielkim rozweseleniem kościoła i radością ludu pospolitego".

Pod datą 1716 odnotowany został organista żywiecki Marcin Skórkowski, pierwszy muzyk, który grał na organach Rysiaka. Zapoczątkował on w Żywcu zwyczaj śpiewania, z towarzyszeniem organów, kantylen o N. Marii Pannie ${ }^{86}$. Dom Marcina Skórkowskiego wymieniono jako drugi przy Rynku na pierzei zachodniej ${ }^{87}$, a zatem w rejonie prestiżowym (lokalizacji domów innych organistów żywieckich nie znamy). Wzmianka o organach wielkich w Żywcu pojawiła się następnie zupełnie przypadkowo pod 1717 r., kiedy Komoniecki odnotował niespotykaną wichurę, która spowodowała otwarcie drzwi kościoła i powstanie wiru pod chórem muzycznym ${ }^{88}$. Nie można wykluczyć, że pojawiły się wówczas jakieś usterki, bowiem w I72I r. podjęto prace remontowe przy organach. W tym roku zakonnik Jakub, z klasztoru karmelitów na Garbarach, przedmieściu Krakowa, przez całe lato remontował i przerabiał organy w Żywcu. Realizował zlecenie dziedzica miasta. Zostały wówczas wymienione miechy i dodany „pozytyw dolni, aby organom korespondował”. Brat Jakub dokonał połączenia pozytywu z głównym, więc odtąd można było grać na obu równocześnie. Organmistrz otrzymywał codziennie „wikt i poczęsność”. Za robotę wypłacono 700 złotych z przeznaczeniem na jałmużnę dla klasztoru karmelitów ${ }^{89}$. $\mathrm{O}$ tych organach zapisano w protokole z 1732 r., że stoją w chórze, są "wspaniałe i wielkie” („magnificum et ingens”), mają dwadzieścia głosów, a ufundował je „na nowo" dziedzic miasta ${ }^{90}$.

Warto zauważyć, że liczba głosów była znacznie mniejsza, niż ta, którą miała dyspozycja Ignacego Rysiaka w I7I4 roku. O ile źródło z 1732 r. nie myli się, przypuszczać można, że karmelita Jakub zmniejszył liczbę głosów. Jego dzieło nie zachowało się. Dzisiejszy instrument w kościele żywieckim jest efektem późniejszych inwestycji, zwraca jednak uwagę fakt, że piszczałki znajdują się w późnobarokowej

85 Surowiec ten był ceniony, skoro piszczałka i cyna były w I6I8 r. w posiadaniu jednego z sądzonych w Żywcu złoczyńców, zob.: Księga ztoczyńców albo akta sądu koniecznego gajonego żywieckiego z lat 1589-I762, wyd. Rafał Kosiński, Żywiec 20I4, s. 63. Niewątpliwie pochodziły z kradzieży z kościoła.

86 A. Komoniecki, op. cit., s. 478-479 (jest zacytowany tekst kantyleny o N. Marii Pannie).

87 Wykaz domów z i715 r. zob.: A. Komoniecki, op. cit., s. 466.

88 Ibid., s. 500.

89 Ibid., s. 534. Na stronie Organmistrzostwo Bałchan, www.organypiszczalkowe.pl/zywiec.html, dostęp I5 XII 20I9, błędnie podano, że Jakub pochodził z klasztoru karmelitów tzw. bosych. Komoniecki wymienia klasztor na Garbarach, tam zaś znajdowali się karmelici trzewiczkowi.

90 AKM, AVCap. 6I, s. I088. 
szafie zdobionej motywami roślinnymi z postaciami grających aniołków i putt. Bez dokładnych badań trudno jest jednak stwierdzić, czy szafa ta jest pozostałością starych organów z czasów karmelity Jakuba9 ${ }^{1}$. Należy podkreślić, że w kościele żywieckim były w II poł. XVII w., oprócz organów głównych, także pozytywy. W I685 r. istniał pozytyw szkatulny na małym chórze w prezbiterium, ale został przeniesiony do innego kościoła, gdyż z fundacji mieszczańskiej powstał nowy instrument, a mianowicie pozytyw stojący. W tym roku Barbara Frankiewiczówna, wdowa po mieszczaninie Marcinie Ząbku, ufundowała pozytyw, który stanął na małym chórze przy ołtarzu głównym kościoła w Żywcu. Realizowała testament męża z II kwietnia. Zmarły sfinansował budowę chórku pod pozytyw, zbudowany przez organmistrza Marcina Fabrycjusza92, a zatem tego samego, który przebudował organy na chórze zachodnim. Co ciekawe, w I702 r. wzmiankowane są „stare organy” w kościele parafialnym żywieckim. Stały one przy północnej ścianie w kaplicy Wniebowzięcia N. Marii Panny, ale przeniesiono je, gdyż w I702 r. w tej ścianie wybito nowe okno93. Oprócz organów chórowych byłyby zatem na przełomie XVII/XVIII w. jeszcze dwa pozytywy (jeden określany jako „stary”, drugi zaś to dzieło Fabrycjusza). Co się z tymi organami stało, Komoniecki nie podaje. Niewątpliwie strawił je, wraz z organami głównymi i całym wyposażeniem wnętrza, pożar z I7II roku. W to miejsce wybudowano, jak wspominaliśmy, nowe organy główne i przynajmniej jeden przenośny pozytyw, gdyż w I732 r. wykazano organy przenośne w kaplicy św. Antoniego ${ }^{94}$.

Dwa inne, małe kościoły Żywca zostały wyposażone w instrumenty stosunkowo późno. Około I685 r. pozytyw szkatulny z prezbiterium kościoła parafialnego ofiarowano do kościoła św. Krzyża i zainstalowano jako stojący. W opisach tego miejsca wzmiankowany jest chór „zatylni” - niewątpliwie na nim stanął ów pozytyw ${ }^{95}$. O kościele św. Marka czytamy pod I70o r., że mszy ku czci Matki Boskiej Anielskiej 2 sierpnia towarzyszyła gra pozytywu ${ }^{96}$. Pochodzenie tego instrumentu nie jest znane. Nie wiemy, czy był tam stałym elementem wyposażenia, czy też przyniesiono go z uwagi na uroczystość religijną. Po instrumentach tych wszelki ślad zaginął.

Żywiec był także ośrodkiem muzyki dworskiej. Pierwszy przekaz dokumentujący muzykę na zamku żywieckim pochodzi z I605 roku. Mikołaj Komorowski, wspomniany już złej sławy dziedzic, zapragnął zabawy na zamku, więc najpierw „posłał po muzykę”, a następnie kazał sprowadzić sobie panny z miasta. Nie wie-

9I Organmistrzostwo Bałchan, www.organypiszczalkowe.pl/zywiec.html, dostęp I5 XII 20I9, Co ciekawe,

Katalog zabytków sztuki (t. I, Województwo krakowskie, red. Jerzy Szablowski, Warszawa I953, s. 542) podaje, że w Żywcu nadal istnieją organy „późnobarokowe” z l. I713-I4.

92 A. Komoniecki, op. cit., s. 239-240.

93 Ibid., s. 283.

94 AKM, AVCap. 6I, s. I087.

95 A. Komoniecki, op. cit., s. 240 i s. 2IO (wzmianka o chórze zatylnim).

96 Ibid., s. 268. 
my, w jaki sposób to sprowadzenie się odbyło, w każdym razie nastawał na cnotę Anny Boczkowczanki, która, nie mogąc bronić się, wyskoczyła przez okno. Podczas upadku straciła oko. W ramach rekompensaty właściciele Żywca nadali rodzinie panny sztukę roli97. Pozostawiając na boku aspekt obyczajowy, skądinąd niezwykle interesujący, zwrócić musimy uwagę na wzmiankę o „posłaniu po muzykę”. Komoniecki na zamku raczej nie bywał, wzmianka ta dotyczy czasów, których nie mógł znać z autopsji. Jego relacja to tylko odprysk tego, co wiedzielibyśmy, gdyby zachowały się źródła dworskie z czasów Komorowskich. Skupiwszy swą uwagę na stronie obyczajowej wydarzenia, poskąpił niestety szczegółów dotyczących kapeli, która przygrywała na zamku tej feralnej nocy. Wiedzę o muzykach dworskich możemy czerpać tylko ze źródeł pośrednich. Sebastian Veniqua, pierwszy znany z nazwiska organista kościoła parafialnego, wskazuje na obecność w Żywcu muzyka z Italii. Czy byli także jacyś inni muzycy, może też Włosi, utrzymywani z kasy Komorowskich? Wzmianka o „posłaniu po muzykę” zdaje się na to wskazywać. Najbardziej interesujący wątek w opowieści Komonieckiego dotyczy muzyków dworskich dających koncerty na wieży kościoła parafialnego. Po raz pierwszy o tym, że muzyka z wieży kościoła grana była przez całą oktawę Narodzenia N. Marii Panny (jest to święto kościoła parafialnego) czytamy pod datą i656. Zwyczaj ten miał dawną metrykę, a w I656 r. wznowiono go staraniem Krzysztofa Mrzygłodowica pisarza dekanatu żywieckiego i pisarza miejskiego ${ }^{98}$. Także pod datą I704 czytamy o tym zwyczaju, któremu, zgodnie z przekazem, towarzyszyło zapalanie świateł na wieży ${ }^{99}$. Muzykę na wieży grano także dla uświetnienia ważniejszych wydarzeń. Przykładem może być przyjazd do miasta dziedzica Franciszka Wielopolskiego w i694 roku. Muzyka i śpiew rozległy się wówczas z wieży kościoła parafialnego ${ }^{\text {Ioo }}$, wyróżniającej się wysokością wśród większości budowli sakralnych polskich miast. Wzniesiona przez mistrzów włoskich i krakowskich w 1. 1582-85 konstrukcja ma loggię wznoszącą się na wysokości 45 metrów i do dziś zachwyca pięknem architektury ${ }^{\text {IOI }}$. Można sobie wyobrazić, że muzyka z wieży niosła się daleko, słychać ją było nie tylko w mieście, ale i zapewne w okolicznych wsiach ${ }^{102}$.

97 Ibid., s. II3.

98 Ibid., s. 195 .

99 Ibid., s. 294.

IOo Ibid., s. 254.

IoI Dane o wysokości wieży (45 m bez hełmu) i czasie budowy za: Katalog zabytków, op. cit., s. 542; zob. także interesującą analizę w: Tadeusz Chrzanowski, Marian Kornecki, Sztuka ziemi krakowskiej, Kraków 1982, s. 232. Brak jest w naszej literaturze monograficznego ujęcia zarówno dziejów kościoła parafialnego w Żywcu (zob.: Michał Rożek, „Przemiany artystyczne fary żywieckiej”, Karta Groni 7-8 (1976), s. 99-II3), jak i tamtejszego zamku.

IO2 Obecnie w Żywcu w południe z głośnika na budynku rady miejskiej rozlega się hejnał grany na trąbkach, odtwarzany z taśmy. Nasuwa się refleksja, że w dziedzinie kultury muzycznej nastąpił znaczący regres w stosunku do stanu z połowy XVII wieku. 
Pod 1722 r. Komoniecki podaje bardzo ważną wiadomość, że trębacze dworscy grali muzykę podczas procesji żywieckiego Bractwa Różańcowego na Jasną Górę ${ }^{\mathrm{IO}}$. W kolejnych zapiskach o muzyce granej podczas procesji, które poniżej przytoczymy, związek muzyków z kapelą dworską nie został przez Komonieckiego podkreślony. I tak, w zapisce z 4 VI I722 r. pojawia się wiadomość o muzyce granej na trąbkach podczas procesji Bożego Ciała w Żywcu. Procesja tradycyjnie okrążała rynek ${ }^{104}$. Wcześniej trębacze ukazywani byli w kontekście służby zamkowej, więc w tym przypadku można sądzić, że to oni grali muzykę podczas procesji. Zapewne towarzyszyli im jacyś inni muzycy amatorzy, relacje Komonieckiego uwidaczniają bowiem w tych momentach pewną masowość muzykowania. Nie ma jednak podstaw, aby sądzić, że w Żywcu istniała odrębna od zamkowej kapela miejska. 20 IX I724 r., w wigilię św. Mateusza, grana była muzyka przy procesji bractw św. Anny i św. Barbary przybyłych do Jeleśni z Milówki oraz Bractwa Różańca z Żywca. Autor podaje, że „kapela muzyki różnej ogłos uczyniła i wszystkich zgromadzonych rozweseliła”. Wzmiankuje muzykę na „różnych instrumentach”, jednak szczególnie dominujące było chyba „trąbienie”, zwłaszcza podczas wchodzenia bractw do kościoła. Towarzyszyło temu przedstawienie, w którym ważną rolę miały postacie odgrywające świętych. W kościele grała wówczas kapela składająca się z różnych instrumentów, a impreza trwała

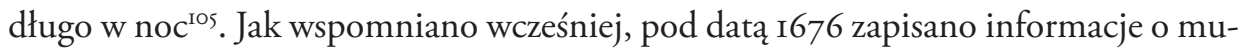
zyku grającym na puzonie, nieznanym z nazwiska muzyku niemieckim ${ }^{\mathrm{I06}}$. W I709 r. wzmiankowany jest Włoch Luparini, instrumentalista dworski z Żywca, który z polecenia dziedzica nadzorował wydobywanie srebra w górze Łyska w Potoku Wilczym, w granicach miasta. W I7I3 r. jego córka została przypadkowo postrzelona w nogę podczas procesji ${ }^{\mathrm{I} 7}$. Pod I7I2 r. czytamy, że Melchior Makowski „muzyk pański” zmarł ze zmęczenia podróżą ${ }^{108}$. Nie wiemy, na jakich instrumentach grali Luparini i Makowski. W I706 r. wzmiankowany jest grający zawodowo na skrzypcach Marcin Kamieniarz z Żywca, którego ukazano w dość specyficznym kontekście. Komoniecki dodaje, że z lubością oddawał się on pijaństwu, ale przyszło na niego otrzé́wienie, bo gdy był w Piotrkowie, ukazała mu się postać z oczami ognistymi, „stąd gorzałkę poprzestał pić i nigdy nie pił, choć skrzypkiem był” ${ }^{\prime \circ}$. Interesujące jest przekonanie autora, że jeżeli muzyk był skrzypkiem, to miał skłonność do pijaństwa. Niewątpli-

I03 A. Komoniecki, op. cit., s. 540-54I. Jak się dowiadujemy, bębnów użyto także przy szczególnej okazji w I705 r., kiedy ośmiu łotrzyków uciekło z więzienia na zamku, na rynku bito w bęben na alarm, a towarzyszył temu dźwięk dzwonu, por.: A. Komoniecki, op. cit., s. 296.

IO4 Ibid., s. 54I.

IO5 Ibid., s. 55I.

Io6 Zob. ibid.

I07 Ibid., s. 335, 422.

Io8 Ibid, s. 38I. Lupariniego i Makowskiego nie odnotowano w wykazie domów mieszczańskich z I7I5 r. (A. Komoniecki, op. cit., s. 466-469), prawdopodobnie więc mieszkali w oficynie zamkowej.

Io9 A. Komoniecki, op. cit., s. 303. 
wie wchodził on w skład kapeli zamkowej, choć nie jest to bezpośrednio poświadczone $^{\text {IIO }}$. Wzmianka o tej kapeli figuruje pod $1715 \mathrm{r}^{\text {III }}$. W zapiskach z tegoż roku odnajdujemy wiadomość o uroczystościach pogrzebowych dziedziczki Zofii Rutkowskiej, cześnikowej płockiej, która zmarła na zamku żywieckim wskutek powikłań poporodowych. Pochowano ją w kościele żywieckim w krypcie, w sąsiedztwie grobu kasztelana sądeckiego Krzysztofa Komorowskiego. W nabożeństwie uczestniczyli kapłani z całego dekanatu żywieckiego oraz bracia reformaci z klasztoru w Kętach. Grała kapela muzyków i wokalistów, którym towarzyszyły organy ${ }^{\text {II2 }}$. W I72I r. trębacze i kapela dworska grali na zamku dla zabawienia ważnych gości dziedzica ${ }^{113}$. Kapela ta dawała koncerty w kościele parafialnym, a zatem koncerty, których słuchaczami byli mieszczanie. Pod datą 1715, relacjonując czasy sobie współczesne, Komoniecki pisze, że dziedzic Franciszek Wielopolski grał na skrzypcach „z nut i partesów”, wraz ze swoją kapelą na chórze, gdzie są organy, a było to II czerwca we wtorek, podczas sumy. Dziedzic grał i dyrygował przez całą sumę. Kolejne muzykowania urządzane były w trakcie oktawy Bożego Ciała oraz w inne święta ${ }^{\mathrm{II}}$. Oprócz tego, autor odnotowuje koncerty dla mieszczan, których wykonawcami byli, co ciekawe, właściciele miasta. Wiemy już, że Franciszek Wielopolski grywał na skrzypcach. Pod rokiem I714 w Wielką Środę wystąpiły w kościele panie Wielopolskie, starsza i młodsza. Anna z Lubomierza (de domo Lubomirska) dziedziczka i Maria Wielopolska córka dziedzica stanęły przed wielkim ołtarzem kościoła w Żywcu i zaśpiewały z nut lamentacje proroka Jeremiasza, „przegradzając się na przemiany". Akompaniowały im klawicymbał i wiola ${ }^{115}$. W I7I7 r. Anna, żona Franciszka Wielopolskiego, śpiewała przy organach w kościele parafialnym z nut „modą francuską”, „głosem wdzięcznym i uprzejmym”. Muzyką tą „kościół rozweseliła i ozdobiła" ${ }^{\text {II }}$. Ostatni z opisywanych przez Komonieckiego koncertów odbył się podczas sumy na święto Wniebowzięcia N. Marii Panny w I725 roku. Grały wówczas panny Maria Franciszka Wielopolska, córka dziedzica, a zarazem klaryska klasztoru krakowskiego wraz z dwiema innymi klaryskami (Prażmowską

IIO Pośrednią przesłanką, że Marcin Kamieniarz był muzykiem zamkowym, jest fakt, iż nie odnotowano go w wykazie mieszkańców domów mieszczańskich z 1715 r. (wykaz ten podał Komoniecki, op. cit., s. 466-469).

III A. Komoniecki, op. cit., s. 460 .

II2 Ibid., s. 466.

II3 Ibid., s. 535 .

II4 Ibid., s. 460.

IIs Ibid., s. 446. Jakub Kubieniec uważa, że wykonano wówczas francuskie Leçons de ténèbres. Autor wskazuje także funkcjonujące wówczas wydania drukiem nut tych utworów, zob.: Jakub Kubieniec, „Treny Jeremiasza w polskiej liturgii potrydenckiej”, w: Muzyka jest zawsze wspótczesna. Studia dedykowane Alicji Jarzębskiej, red. Małgorzata Woźna-Stankiewicz, Andrzej Sitarz, Kraków 20II, s. 269-284, zob. zwłaszcza s. 274 .

II6 A. Komoniecki, op. cit., s. 49I. O wykonaniu „pieśni w języku francuskim” zob. też: Stanisław Mączka, „Życie religijne żywiecczyzny w okresie kontrreformacji”, Karta Groni 6 (1974), s. 20-30. 
i Węgrzynowicówna). Utwory, nieznane nam niestety, wykonywały z nut na skrzypcach z towarzyszeniem organów ${ }^{117}$.

Przekaz wizualny odgrywał w dawnych wiekach niezwykle ważną rolę edukacyjną. Zazwyczaj to stwierdzenie pojawia się przy analizie treści religijnych widocznych na tympanonach, polichromiach, ołtarzach i obrazach. Dawny Żywiec dostarcza bardzo interesującego przykładu dotyczącego wizualizacji treści muzycznych. Komoniecki, odnosząc się do zagadnienia odnowienia kościoła w I7I2 r., opisał wygląd dawnego fresku na sklepieniu z czasów Komorowskich noszącego datę I542. Na sklepieniu były przedstawione postacie aniołów grających na instrumentach. W ich rękach ukazano skrzypce, kornet, harfę, lutnię, wiolę, pozytyw, trąbę i puzon. Przedstawiony został także chór aniołów śpiewających z nut ${ }^{\mathrm{II}}$. Fresk w kościele parafialnym dawał mieszkańcom Żywca przynajmniej podstawową wiedzę na temat niektórych instrumentów i świadczył także o tym, że muzyka była w dawnym Żywcu grana publicznie.

Zebrane przez nas informacje, pochodzące głównie z dzieła Komonieckiego i nielicznych innych źródeł, składają się na obraz kultury muzycznej małego polskiego miasta w okresie staropolskim. Istniał w nim zarówno kościół, co jest oczywiście elementem typowym dla urbanizacji staropolskiej, jak i zamek, co z kolei czyni przykład Żywca wyjątkowym. O specyfice kultury muzycznej zadecydowała obecność i oddziaływanie zamku. Inną specyfiką Żywca było przenikanie się elementów kultury miejskiej i kultury ludowej. O muzyce ludowej świadczą wzmianki o tańcach i graniu w karczmie, odnotowane pod 1620 r. zapiski o tańcach, które wieńczyły pracę przy dzierganiu lnu, liczne opisy procesji, którym towarzyszyły śpiewy i muzyka, czy wspominana już „wesoła” pieśń, którą śpiewał torturowany łotrzyk. Za bardzo cenną należy uznać informację Komonieckiego z 1716 r., a więc z czasów mu współczesnych, o wykonaniu na życzenie dziedzica tańca i muzyki góralskiej na zamku żywieckim. Widać z tych relacji, że autor Chronografii zdradzał pewne zainteresowanie muzyką, aczkolwiek gdyby drobiazgowo analizować jego informacje, to okazuje się zazwyczaj, że wzmianki o niej pojawiają się przy okazji omawiania innych spraw. Wydaje się jednak, że autentycznie zainteresowany był tylko niektórymi wydarzeniami - budową organów w miejscowym kościele oraz koncertami dawanymi przez członków familii Wielopolskich, których słuchaczami byli także mieszczanie żywieccy.

W kulturze muzycznej miasta kościół i zamek odgrywały niezwykle ważną rolę, ale jeśli idzie o udział mieszczan w muzyce, to pierwszeństwo przyznać trzeba niewątpliwie kościołowi. Msze śpiewane pojawiły się w kościele żywieckim zapewne już w XV wieku. Dzieło Komonieckiego dostarcza licznych przykładów konkretnych pieśni, litanii, psalmów itp. Poświadczony jest od połowy XVI w. fakt, że w kościele

II7 A. Komoniecki, op. cit., s. 554. Skoro koncert odbył się w I725 r., to niewątpliwie akompaniowano na organach wybudowanych przez karmelitę Jakuba. Nazwisko organisty nie jest niestety znane.

II8 Ibid., s. 374 . 
żywieckim rozbrzmiewały organy (które pojawiły się tam zapewne jeszcze wcześniej). $\mathrm{Z}$ historią tego instrumentu wiążą się nazwiska takich organmistrzów, jak Stanisław Bartodziejski (I585), Marcin Fabrycjusz (I686), Jan Głowiński z Krakowa (I7I2), Ignacy Rysiak z Opawy (I7I4) i karmelita Jakub z Garbar pod Krakowem (I72I). Wielkie, trzydziestogłosowe organy w kościele parafialnym ufundowali dziedzice miasta, wnioskować więc można, że miejscowość wielkości Żywca nie byłaby w stanie podołać finansowo takiej inwestycji. Na przykładzie Żywca można stwierdzić, że w XVIII w. organy liczące trzydzieści głosów powstawały w ciągu dwóch lat. Dziedzice miasta, począwszy od Komorowskich, dbali o stałą pensję muzyków zarówno swojej kapeli, jak również kantora i organisty w kościele parafialnym. Na uposażenie muzyków pracujących w kościele składali się także proboszcz, rada miejska i niektórzy mieszczanie.

W Żywcu poświadczona jest muzyka wykonywana przez dworskich muzyków na takich instrumentach, jak trąbka, puzon, skrzypce, wiola i klawicymbał. Mimo szczegółowej kwerendy nie uzyskaliśmy żadnych informacji o instrumentach ludowych, nie licząc drewnianych instrumentów, na których naśladowano głosy ptaków. Wydaje się, że tam, gdzie czytamy o muzyce podczas procesji, grano przede wszystkim na instrumentach dętych. Muzykę na zamku uprawiano zarówno za czasów Komorowskich, jak i Wielopolskich, przy czym niezwykle ciekawym zjawiskiem jest wyraźny brak ekskluzywizmu. Wytworzyła się bardzo interesująca sytuacja - kościół parafialny stał się miejscem uprawiania muzyki zarówno kościelnej, jak i tej wykonywanej przez kapelę dworską. Muzycy dworscy grali także dla mieszczan (słynne koncerty z wieży kościoła parafialnego), dla których koncerty w kościele urządzali także Wielopolscy.

Trzeba mieć oczywiście świadomość, że obraz kultury muzycznej, jaki daje Chronografia Komonieckiego z pewnością nie jest pełny. Księgi miejskie, testamenty i rachunki dworskie pozwoliłyby na niejedno uzupełnienie. Wątpliwe jednak, czy nawet mając te źródła, uzyskalibyśmy aż tak wiele fascynujących szczegółów, jakie przynosi dzieło wójta żywieckiego. Powracając na grunt rzeczywistej bazy źródłowej należy stwierdzić, że gdyby Chronografii nie było, to nasza wiedza o kulturze muzycznej Żywca ograniczałaby się do paru wzmianek z protokołów powizytacyjnych i zachowanych fragmentów mszałów. Dzięki kronice Komonieckiego, która w okresie I689-I728 przybiera charakter zapisek prowadzonych miesiąc po miesiącu, niekiedy dzień po dniu, można bardzo wiele dowiedzieć się o kulturze miejskiej Żywca. Szkoda, że inne miasta nie doczekały się takiego dzieła. 
MUSIC IN HISTORICAL ŻYWIEC. THE UNIQUE SIGNIFICANCE

OF ANDRZEJ KOMONIECKI'S CHRONOGRAPHY

The author's main research aim was to analyse a work by Andrzej Komoniecki, alderman of the town of Żywiec, in Lesser Poland, entitled Chronografia albo Dziejopis Żywiecki [Chronography, or Żywiec chronicle]. This chronicle, covering the period up to 1728 , is an extremely valuable source for the study of the urban culture of Żywiec during the Old Poland period. Detailed analysis has revealed very numerous and valuable information concerning music, in most cases entered under specific year dates, which provides a point of departure for the study of music in old Żywiec. All the music-related information from Chronography is presented under three headings: folk, church and court music. The first of these groups is relatively small, but there are notable mentions of dancing and music-making in an inn, a song sung by a convict, and, most interestingly, a relatively detailed description of highlander dances and music from the year 1716. The lively development of sacred music is evidenced by numerous mentions of altarists, cantors, parish school teachers (some of whom were instrumentalists) and organists. Especially detailed is the information concerning the organ in the parish church. Another extremely valuable item is the description of a fresco from I542, no longer existing, which depicted figures playing various instruments. This description proves that the town's owners enjoyed very close links to the parish church. As for court music, an ensemble probably existed at Żywiec Castle as early as the sixteenth century. Collected in this article is all the available information concerning court music in Żywiec. Of special interest are the mentions of concerts held in the church during which family members of the town's owners performed. There are also multiple mentions of music played from the church tower by the court trumpeters.

Translated by Tomasz Zymer

Słowa kluczowe / keywords: Żywiec, kościół / church, muzyka ludowa / folk music, organy / organs, muzyka dworska / court music, msze śpiewane / sung masses, pieśni religijne / religious songs, muzyka góralska / highlander music

Prof. dr hab. Jerzy Rajman kieruje Katedrą Historii Średniowiecznej w Instytucie Historii Uniwersytetu Pedagogicznego w Krakowie. Zajmuje się historią Polski średniowiecznej, prowadzi badania nad dziejami zakonów, kultów świętych, historią Krakowa i osadnictwa Małopolski średniowiecznej (sylwetka naukowa i pełny wykaz publikacji na stronie www.up.krakow.pl). jerzy.rajman@poczta.fm 